\title{
International diversification and firm's value: evidence from developing nations
}

\begin{abstract}
Purpose: This paper aims to evaluate the impact of international diversification, through the investment abroad activities of the Malaysian multinational corporations (MNCs), on their financial performance. Design/methodology/approach: The paper applies the panel generalized method of moments (GMM) estimation technique that gives better results. Findings: The empirical findings show that the move to invest abroad has brought a positive impact on Malaysian MNCsôfinancial performance. However, in terms of a firmôs risk, the results contradict the general internationalization-risk hypothesis. Research limitations/implications: The study focuses on the top 100 multinational firms; future researchers may extend the time period and use the entire sample of all the multinational firms. Practical implications: Foreign investments offer rewarding returns due to cheaper labour and raw materials, competitive edge in terms of technological advancement and larger market opportunities. Originality/value: The paper contributes to the literature using the panel GMMôs estimation that effectively control for reverse causality and serial correlation problem. The paper also contributes to the international diversification and performance relationship, in a fast-growing Malaysia.
\end{abstract}

Keyword: Malaysia; Firm performance; Risk; Tobinôs Q; Multinationalization; Panel GMM 